National Laboratory for Veterinary Quality Control on Poultry Production, Animal Health Research Institute, Dokki, Giza, Egypt.

\title{
DIFFERENTIATION BETWEEN VACCINE AND FIELD STRAINS OF TURKEY RHINOTRACHEITIS VIRUS (TRTV) BY PARTIAL SEQUENCING OF FUSION (F) GENE
}

(With 2 Tables and One Figure)

By

\section{A. ARAFA and HANAN. A. FAHMY*}

*Dept. of Biotechnology, Animal Health Research Institute, Dokki, Giza, Egypt.

(Received at 22/4/2009)

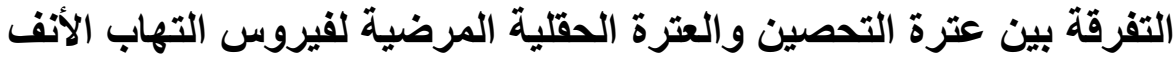

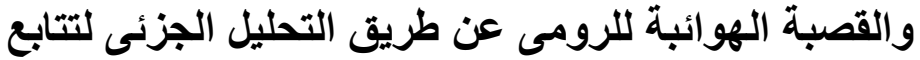

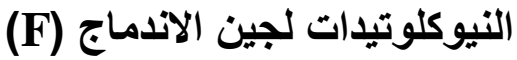

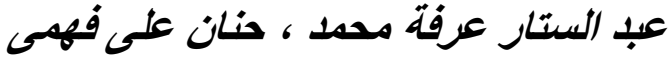

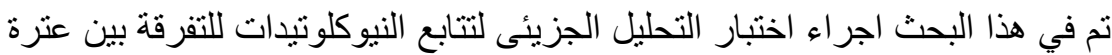

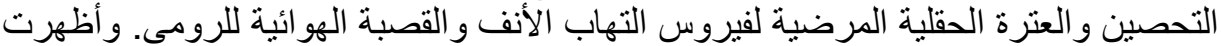

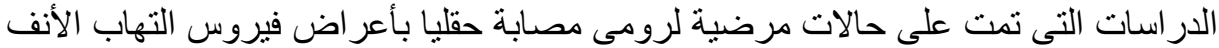

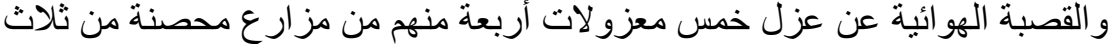

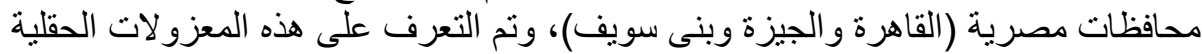

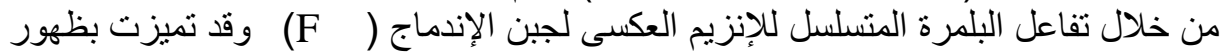

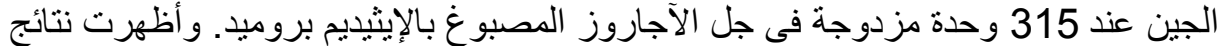

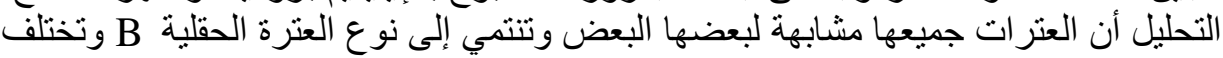

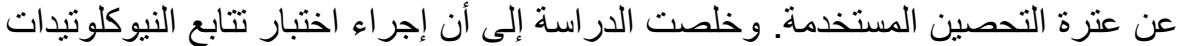

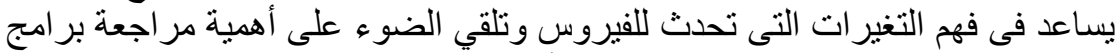

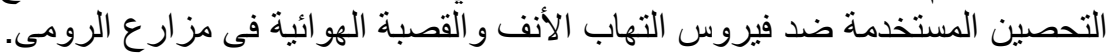

\section{SUMMARY}

Subsequent nucleotide sequencing analysis is described to characterize turkey rhinotracheitis virus (TRTV) field isolates and vaccine strains. Five isolates of avian metapneumovirus (aMPV) were isolated from field cases in turkeys with clinical signs of rhinotracheitis. Four out of 
the five isolated strains were obtained from vaccinated turkey farms from 3 Egyptian governorates (Cairo, Giza and Beni-suif). These field isolates of aMPV were amplified by RT-PCR for the fusion $(\mathrm{F})$ gene. A 315 base pair fragment of PCR product was detected by ethidium bromide staining in agarose gel. The amplified fragments were sequenced and compared with other field and vaccine strains. Phylogenetic analysis of field and vaccine strains revealed that the 5 isolates were closely related to each other and very close to field isolates from type B European strains and distinct from the vaccinal strains used. The data from this work revealed that sequence information helps us understand the evolution and dissemination of viruses and spot the light to the currently used vaccines against TRT in turkey farms.

Key words: Turkey rhinotracheitis virus, sequence of $F$ gene, differentiation between field and vaccine strains

\section{INTRODUCTION}

Avian metapneumovirus (aMPV) previously referred to as avian pneumovirus (APV) and avian rhinotracheitis (ART) virus causes an acute, highly contagious upper respiratory tract infection of turkeys and chickens. In turkeys, the virus causes a disease known as turkey rhinotracheitis (TRT) (OIE, 2008).

Avian metapneumovirus (AMPV) is an important pathogen causing respiratory disease and egg drops in several avian species. Four AMPV subgroups have been identified A, B, C and D (Guionie et al., 2007). The causative agent avian metapneumovirus belongs to Order Mononegavirales, Family Paramyxoviridae subfamily Pneumovirinae which has 2 genera Pneumovirus and Metapneumovirus. Avian metapneumoviruses also known as avian rhinotracheitis virus (ARTV) Turkey rhinotracheitis virus (TRTV) are single-stranded non-segmented negative-sense RNA viruses belonging to genus Metapneumovirus (OIE, 2008).

ARTV affects both turkeys and chickens and is known to be the primary causative agent of turkey rhinotracheitis (TRT) and Swollen head syndrome (SHS) respectively (Gough, 2003). The characteristic swollen head appears as a result of infection with secondary adventitious bacteria, usually Escherichia coli. Early reports attributing a viral etiology to both TRT and SHS in chicken came from South Africa where both diseases had appeared during 1970s. Some years later, TRT was 
reported in Europe, Israel, South America, Middle and Far East as well as USA (Hafez, 2005).

On the bases of sequencing of the surface glycoprotein "G", aMPV can be divided into two important subtypes A and B (Juhasz and Easton, 1994). The low sequence homology, being only 38\% between attachment proteins of different isolates allowed the establishment of PCRs to differentiate between A and B. In addition a third subtype, designated as subtype $\mathrm{C}$ was reported from USA, mainly Colorado and Minnesota. Sequence studies of the M gene (Seal, 1998) and $\mathrm{F}$ gene (Seal et al., 2000) indicate the assignment of new subtype. Finally a specific situation is reported from France, where non -A, non $\mathrm{B}$ viruses were isolated from turkeys and a Colorado - like pneumovirus from Muscovy duck, all of them in combination with respiratory signs in the respective host (Toquin et al., 1999).

The UK isolates were judged to the type A and other isolates from Europe to the type B, confirmed that outbreaks of respiratory diseases in turkeys in UK during 1994 to 1995 were still associated to APV as subtype B (Naylor et al., 1997). In Germany both type A and B could be detected in both turkey and chicken isolates from 1987 - 1991 using type- specific RT- PCR (Hafez et al., 2000).

Subsequent studies sequences between the two subgroups so that the genetic composition of these genes could also be used to distinguish between the subgroups (Randhawa et al., 1996). The nucleotide sequence of a fragment of the APV- US Fusion gene was determined and used to develop PCR based assay in RNA extracts of tracheal swabs and turbinate homogenates (Dar et al., 2001).

Laboratory diagnosis of aMPV infections relies on serological methods, on labor intensive virus isolation procedures and on recently developed subgroup specific RT- PCR (Guionie et al., 2007). Molecular procedures based on the $\mathrm{F}, \mathrm{G}, \mathrm{M}$ and $\mathrm{N}$ genes of aMPV have been used for the detection and or genomic subtyping of aMPV. Conventional reverse-transcriptase polymerase chain reaction (RT-PCR) procedures can also be used for aMPV A and B genomic subtyping. Moreover, nucleotide sequence analysis of the gene encoding the protein (OIE, 2008). Reverse-transcriptase PCR (RT-PCR) is a significantly more sensitive and rapid method for the detection of aMPV than standard virus isolation methods because of the fastidious nature of aMPV (Cook and Cavanagh, 2002).

Several RT-PCR assays directed to the F, G and M genes have been successfully used for subtype identification of aMPV as well as 
nucleotide sequence and phylogenetic analysis were reported (Goyal et al., 2000; Shin et al., 2002 and Jirjis et al., 2004).

The identification of aMPV types are important aspects in aMPV epidemiology. Therefore the purpose of the work described here was to characterize isolates from aMPV using partial sequencing of the fusion gene $(\mathrm{F})$ and for differentiation between field and vaccine strains of turkey rhinotracheitis virus in vaccinated turkey flocks.

\section{MATERIALS and METHODS}

Field strains: Five isolates of aMPV were isolated from turkeys with clinical signs of rhinotracheitis (Mahmoud et al., 2008) named as GizaTRT-1, Giza-TRT-3, Giza-TRT-4, Beni-suif-TRT-7 and Cairo-TRT-8 sourced from 3 Egyptian Governorates (Giza, Beni-suif and Cairo). The vaccination strategy for the vaccinated flocks were done by applying different regimens either by application of 2 doses (live then killed) in 2 flocks (Giza-TRT-1 and Beni-suif-TRT-7), or by application of 3 doses for 2 flocks (Giza-TRT-3, Giza-TRT-4) by applying (1 killed then 2 live and 2 killed then 1 live respectively) and 1 non vaccinated flock (CairoTRT-8).

Vaccine strain: The live A type vaccine had been derived from UK strain \#8544 (accession number DQ666911).

RNA extraction and RT-PCR: RNA was extracted from isolates from each case by using RNA Extraction kit (QIA amp Viral RNA Mini kit, Cat. No. 52904, Qiagen, Valencia, Calif, USA). Reserve transcription (RT) was performed using an RT random hexamer primers and AMV reverse transcriptase (Roche, Cat. No.13490320), according to the manufacturer's instructions, using $5 \mu \mathrm{l}$ of purified RNA in a $20 \mu \mathrm{l}$ reaction volume and this step was carried on thermal cycler profile of $42^{\circ} \mathrm{C} / 30 \mathrm{~min}$ then $85^{\circ} \mathrm{C}$ for $5 \mathrm{~min}$ (Biometra, Germany). The fusion gene (F) of TRTV isolates were amplified by PCR with primers designed from consensus sequences of aMPV (Shin et al., 2000) as follow: F1 (sense) from position 3558 to 3576 in strain \#8544: 5'CAATTCTCTGAYAGTGCAG, F2 (antisense) from position 3855 to 3872: 5'-GTACCACCCYTGATCTTC

After RT, 5 to $10 \mu \mathrm{l}$ of the reaction mixture was used for PCR. The cDNA was denaturized at $94^{\mathrm{O}} \mathrm{C}$ for $5 \mathrm{~m}$, followed by 35 cycles of denaturation $\left(94^{\mathrm{O}} \mathrm{C}\right.$ for $\left.1 \mathrm{~m}\right)$, annealing $\left(54^{\mathrm{O}} \mathrm{C}\right.$ for $\left.1 \mathrm{~m}\right)$ and elongation $\left(72^{\mathrm{O}} \mathrm{C}\right.$ for $\left.1 \mathrm{~m}\right)$. The expected size of the amplicons is 315 base pair (bp). Each reaction was analyzed by $1.5 \%$ agarose gel electrophoresis and 
stained with ethidium bromide. The PCR products were gel purified (Qiagen, Valencia, Calif.) and sequenced using BigDye Terminator v3.1 Cycle Sequencing Kit on an automatic sequencer (ABI-3130; Applied Biosystems, Foster City, CA). Phylogenetic analysis was carried out on the partial 315 base pair length of $\mathrm{F}$ gene of the Egyptian strains (Fig. 1) where multiple and pairwise sequence alignments were constructed using the ClustalV algorithm and phylogenetic tree were constructed using the neighbour-joining of MegAlign program from LaserGene Biocomputing Software Package (DNASTAR, Madison, WI).

\section{RESULTS}

The amplified part of the $\mathrm{F}$ gene for the 5 field viruses that produced 315 bp RT-PCR products were sequenced and compared with the vaccine strains. (Tables 1 and 2 )

The amino acids sequence comparison of 78 amino acid of $\mathrm{F}$ gene starting from 233 (the numbering started from the beginning of the $\mathrm{F}$ gene). There was one distinct substitution (G264D) and 4 substitutions at positions 294-298 (H294K, R296K, E297G and S298N) identifying the subgroup A from subgroup B and differentiating field from the vaccine strain (\#8544) that referred to the 5 Egyptian isolates were field strains closely related to subgroup B viruses. Analysis of nucleotide sequences relatedness of viral strains for TRT indicates that the five Egyptian viruses were very closely related to each other. Our data indicate that these viruses are related to subtype B viruses isolated from Europe and not related to vaccinal strain UK strain \#8544 (Figure 1).

Fig. 1: Phylogenetic analysis of TRTV field isolates and vaccine strains. 


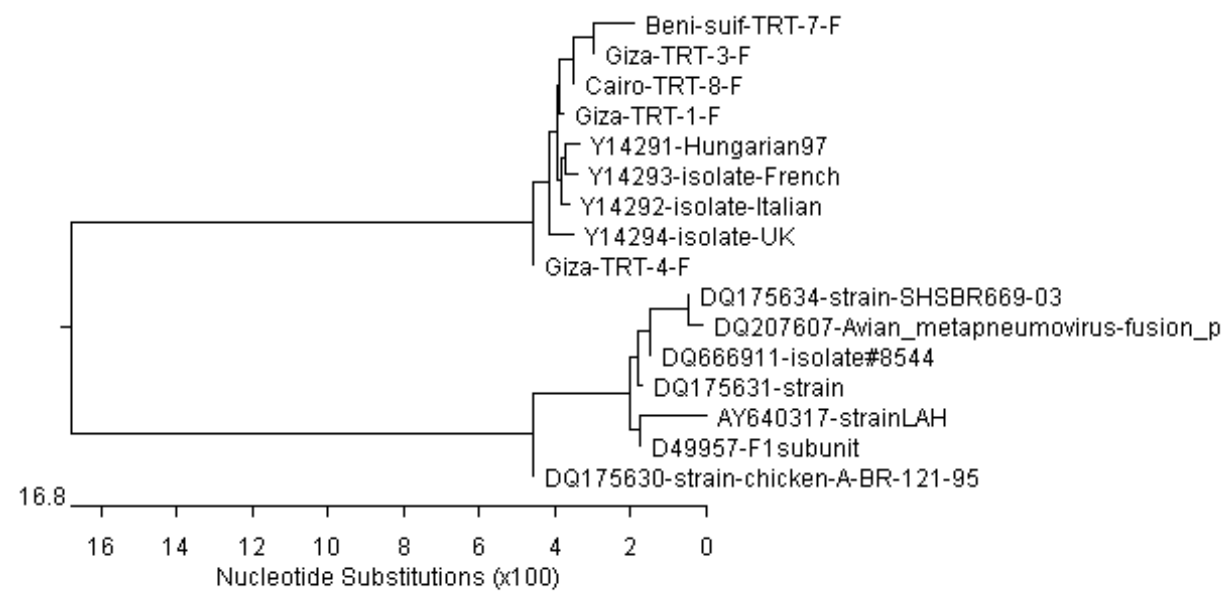

The analysis was done based on fusion (F) protein, sequences aligned by ClastalV method and the tree was built by using Megalign software of DNA star.

Table 1: Nucleotide sequence comparison of field and vaccine strains of turkey rhinotracheitis virus (TRTV) by partial sequencing of $\mathrm{F}$ gene.

Y14291-Hungarian97
Y14292-isolate-Italian
Y14293-isolate-French
Y14294-isolate-UK
DQ666911-isolate\#8544
AY640317-strainfsH
D49957-F1subunit
DQ175631-strain
DQ175630-strain-chicken-A-BR-121-95
DQ175634-strain-SHSBR669-03
DQ207607-Avian_metapneumovirus-fusion-
Beni-suif-TRT-7-F
Giza-TRT-3-F
Giza-TRT-1-F
Cairo-TRT-8-F
Giza-TRT-4-F

Y14291-Hungarian97 Y14292-isolate-Italian Y14294-isolate-UK DQ666911-isolate\#8544 DQ175631-strai DQ175634-strain-SHSBR669-03 DQ207607-Avian_metapneumovirus-fusion_p

Giza-TRT-3-P

Cairo-

Giza-TRT-4-F

\begin{tabular}{|c|}
\hline 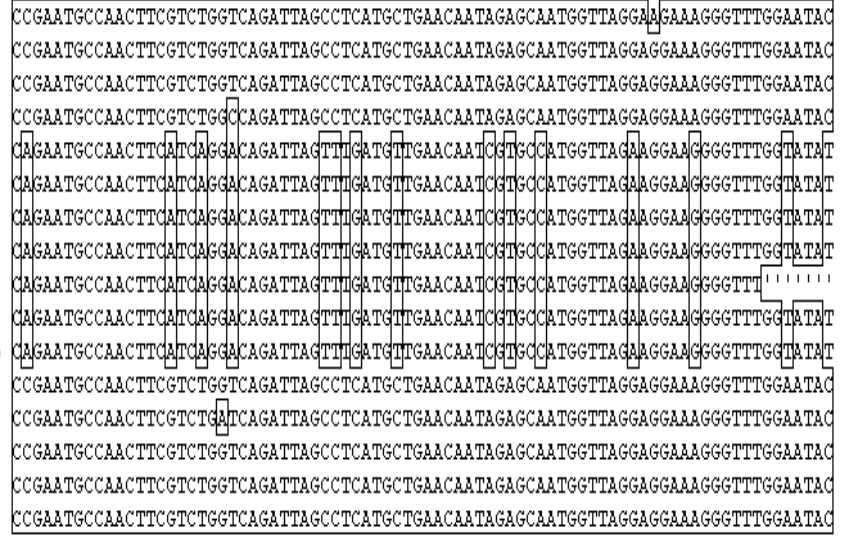 \\
\hline
\end{tabular}

The analysis was done based on fusion (F) gene nucleotide sequences aligned by ClastalV method by using Megalign software of DNA star. 
Table 2: Amino acids sequence comparison of field and vaccine strains of turkey rhinotracheitis virus (TRTV) by partial sequencing of F gene.

Majority

DQ666911-isolate\#8544

Y14290-isolate

Y14291-Hungarian97

Y14292-isolate-Italian

Y14293-isolate-French

Y14294-isolate-UK

Beni-suif-TRT-7-F

Giza-TRT-3-F

Giza-TRT-1-F

Cairo-TRT-8-F

Giza-TRT-4-F

AY640317-straindAH

DQ175631-strain

DQ175634-strain-SHSBR669-03

DQ207607-aMPV-fusion_protein

D49957-F1subunit

DQ175630-strain-chicken-A-BR-121-95
RMP TSSGQISLMLNNRAMVRRKGF GIL IGVYGGTWMMVQLP IF GV IETPCWRVVA.APLCRHERESYACLLREDQGWY

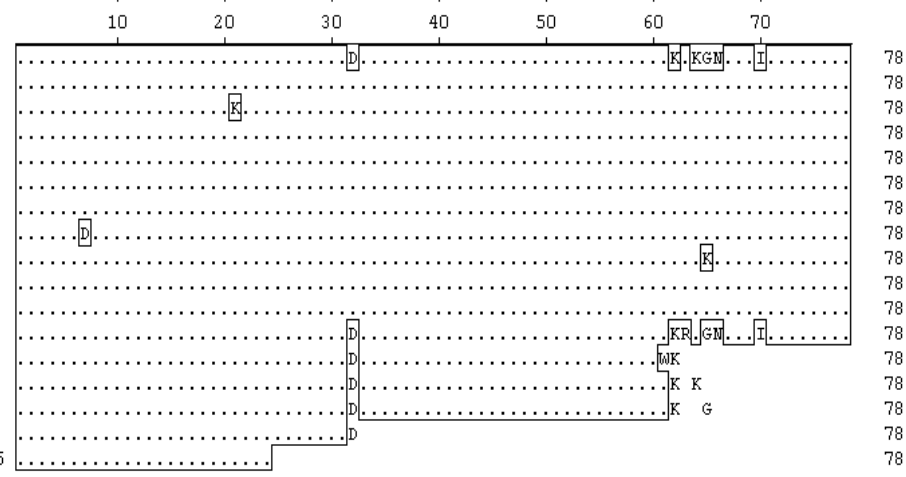

The analysis was done based on fusion (F) gene amino acids sequences aligned by ClastalV method by using Megalign software of DNA star. 


\section{DISCUSSION}

aMPV infections of turkeys have become a major disease threat to the turkey population in all parts of the word. Improved diagnostic methods are required and longitudinal studies on a number of turkey flocks have shown that it is possible to use PCR to detect the presence of APV for several weeks (Naylor et al., 1997). However this technique detects nucleic acid and not live virus.

It has been shown that PCR could be convenient tool for detecting TRTV from esophagus, trachea and nasal sinus (Mahmoud et al., 2008) because it required minimal laboratory facilities and is relatively simple and easy to perform. Our tests were designed specifically for phylogenetic analysis and comparative amino acid sequence between $\mathrm{F}$ gene of field strain of TRTV and vaccine strain. Therefore, we amplified part of the F gene to produce a $315 \mathrm{bp} \mathrm{RT-PCR} \mathrm{product.}$

Group A viruses like UK/3B/85, Republic of South Africa isolates RSA/91/78 and RSA/2381/88, and vaccinal strains like (TRT Vaccine, Living Nobilis, Intervet, and Poulvac, Solvay-Duphar and Nemovac; Merial, Lyon, France). Group B viruses like France/PL86004/86, Fr/PR8602/86, France/PL20, Italy/88, Spain/88, Hungary/89, Dutch isolates NL/2178/90 and NL/6726/90 (Cook et al., 1995), Hungary/99, British field isolate UK/8/94 and vaccinal strains (Aviffa and Nemovac, Rhone Merieux).

APVs were classified into two main subgroups (A and B) both were defined in Europe; these subgroups were initially based on the level of genetic variations in the attachment glycoproteins (G) of APV strains (Juhasz and Easton, 1994).

Present study showed that the TRTV isolated from field was not related to the vaccine strain \#8544 (Figure 1 and Table 1) because the five isolates had a $\mathrm{G}$ nucleotide at position 979 which confirmed these isolates as field strains as indicated by Cavanagh et al., (1999) whose confirmed that the $\mathrm{F}$ gene of vaccine strain did not have a MboII restriction site (GAAGA) at this position because of the $A$ to $G$ substitution.

It was detected previously that the most conserved domain was that encoding the amino terminus of $\mathrm{F} 1$, presumed to be the membrane fusion-related domain, as there was only one, conservative difference among 23 residues. The APV peptide connecting F2 with F1 comprised RKKR and RRRR for the subtype B and A strains, respectively (Naylor et al., 1998). 
In the UK the leading subtype until 1993 / 1994 was subtype A but later on the situation changed and A gave way to B (Naylor et al., 1997). Except two un-typed French isolates from 1985, all other APVs from French belong also to subtype B (Bayon- Auboyer et al., 2000). The fact that APVs with varying pathogenicity circulate in the field could be advantageous for specific virus or subtype (Hess et al., 2000). for optimum efficacy, the live attenuated vaccines are best used at day old, either in the hatchery, or on the farm, whilst the poults are still in boxes as experienced in UK (Cook, 1999) and in Germany (Hafez, 1994). This ensures that each poult receives a full dose of vaccine at that time, thereby avoiding the risk of vaccine virus spreading (Cook et al., 1991). It has been known for many years that maternally derived APV antibodies do not protect turkeys against challenge. Furthermore, because they do not interfere with vaccine take, there is no concern over the efficacy of TRT vaccines following day- old application (Cook et al., 1996).

Vaccination of NDV maternal-antibody-positive broilers chicks against NDV and APV with the vaccines used is unlikely to have adverse effects on the efficacy of either vaccine (Ganapathy et al., 2006).

Fortunately TRT vaccines developed using either A or B strain of APV is highly effective in controlling infection caused by Colorado isolate (Cook et al., 1998). Also, Hess et al., (2000) detected subtype A in flocks vaccinated with subtype B and in areas where only B was used as vaccine. In all non vaccinated flocks mainly subtype A was detected and in two cases with subtype B.

It will be possible to differentiate vaccine and virulent viruses by PCR and sequencing and this would be a major diagnostic tool for playing an important role in helping to optimize the use of TRT vaccines (Cavanagh et al., 1997). Cook et al., (1995) showed that poults vaccinated with type A had reduced clinical signs after challenge with type B TRTV. Also Eterradossi et al., (1995) have reported that poults which had been vaccinated with type B did not show any respiratory signs when challenged with virulent type A or B viruses. In addition Naylor et al., (1997) showed that poults inoculated with virulent strains of A or B induced cross- protection although it was incomplete. Furthermore the identification of robust markers makes it is easy to follow vaccines in the field and this should be of considerable use in the design and interpretation of commercial vaccine field trials (Catelli, et al., 2006). 
In conclusion, the application of molecular techniques like PCR and sequencing may lead to improvements in diagnosis and in differentiation of vaccine and field viruses and that will guide to the reviewing of the vaccination strategies applied in the field and also for development of alternative vaccines when needed. Analysis of genetic sequence of field and vaccine strains could be a helpful tool to differentiate between field and vaccine strains. There was no effective treatment for the primary infection and so good hygiene was not sufficient, but good management and vaccination began to be practiced for control of APV infection. There has been speculation that effective control is better achieved when the vaccine is of the same subgroup as the challenge virus. Sequence information helps us understand the evolution and dissemination of aMPV in the field and knowing the circulated strains in Egypt and that will guide to the application of efficient control strategy.

\section{REFERENCES}

Bayon-Auboyer, M.H.; Arnauld, C.; Toquin, D. and Eterradossi, N. (2000): Nucleotide sequences of the F, L and G protein genes of two non-A/non-B avian pneumoviruses (APV) reveal a novel APV subgroup. J. Gen. Virol. 81, 2723-2733.

Catelli, E.; Cecchinato, M.; Savage, C.E.; Jones, R.C.; Naylor, C.J. (2006): Demonstration of loss of attenuation and extended field persistence of a live avian metapneumovirus vaccine. Vaccine, 24, 6476-6482.

Cavanagh, D.; Mawditt, K.; Shaw, K.; Britton, P. and Naylor, C. (1997): Towards the routine application of nucleic acid technology for avian disease diagnosis Acta Veterinaria Hungarica, 45, 281-298.

Cavanagh, D.; Mawditt, K.; Britton, P. and Naylor, C.J. (1999): Longitudinal field studies of infectious bronchitis virus and avian pneumovirus in broilers using type-specific polymerase chain reactions. Avian Pathol. 28, 593-605.

Cook, J.K. (1999): Turkey rhinotracheitis vaccines- yesterday, today and tomorrow. Published by Hafez, H. and Mazaheri, A. ISBN3-930511-75-4 page 80-86.

Cook, J.K. and Cavanagh, D. (2002): Detection and differentiation of avian pneumoviruses (metapneumoviruses). Avian Pathol., 31, 117-132. 
Cook, J.K.; Ellis, M.M. and Huggins, M.B. (1991): The pathogenesis of turkey rhinotracheitis virus in turkey poults inoculated with the virus alone or together with two strains of bacteria. Avian Pathology 20, 155-166.

Cook, J.K.; Huggins, M.B.; Woods, M.A.; Orbell, S.J. and Mockett, A.P.A. (1995): Protection provided by a commercially available vaccine against different strains of turkey rhinotracheitis virus. Vet. Record 163, 392 - 393.

Cook, J.K.; Orthel, F.; Orbell, S.; Woods, M.A. and Huggins, M.B. (1996): An experimental turkey rhinotracheitis (TRT) infection in breeding turkeys and the prevention of its clinical effects using live-attenuated and inactivated TRT vaccines. Avian Pathology 25, 231-243.

Cook, J.K.; Huggins, M.B. and Senne, D. (1998): Turkey rhinotracheitis-relationship of different virus subgroups. Proceedings of the $1^{\text {st }}$ International Symposium on Turkey Diseases, Berlin. (Published by Hafez, H.M. and Mazaheri, A. -ISBN 3-930511-53-3) p. 89-93.

Dar, A.M.; Tune, K.; Munir, S.; Panigrahy, B.; Goyal, S.M. and Kapur, $V$. (2001): PCR-based detection of an emerging avian pneumovirus in US turkey flocks. J Vet. Diag. Invest. 3 (3): 201-5.

Eterradossi, N.; Toquin, D.; Guittet, M. and Bennejean, G. (1995): Evaluation of different turkey rhinotracheitis viruses used as antigen for serological testing following live vaccination and challenge. Journal of Veterinary Medicine (B) 42, 175 - 186.

Ganapathy, K.; Todd, V.; Cargill, P.; Montiel, E. and Jones, R.C. (2006): Interaction between a live avian pneumovirus vaccine and two different Newcastle disease virus vaccines in broiler chickens with maternal antibodies to Newcastle disease virus. Avian Pathology, 35(6), 429- 434.

Gough R.E. (2003): Avian pneumoviruses. In: Diseases of Poultry, eleventh edition, Saif Y.M., Barnes H.J.,Glisson J.R., Fadly A.M., McDougald L.R. and Swayne D. eds. Blackwell Publishing, 92-99.

Goyal, S.M.; Chiang, S.J.; Dar, A.M.; Nagaraja, K.V.; Shaw, D.P.; Halvorson, D.A. and Kapur, V. (2000): Isolation of avian pneumovirus from an outbreak of respiratory illness in Minnesota turkeys. J. Vet. Diagn. Invest., 12, 166-168. 
Guionie, O.; Toquin, D.; Sellal, E.; Bouley, S.; Zwingelstein, F.; Allee, C.; Bougeard, S.; Lemiere, S. and Eterradossi, N. (2007): Laboratory evaluation of a quantitative real time reverse transcription-polymerase chain reaction assay for the detection and identification of the four subgroup avian pneumovirus. J. Virol. Method. 139 (2): 150-158.

Hafez, H.M. (1994): Die aviären Pneumovirus-Infektionen des Wirtschaftsge-flügels: Ein Beitrag zur Epidemiologie, Ätiologie, Diagnose und Bekämpfung. Habilitation München.

Hafez, H.M. (2005): Respiratory Diseases of Turkeys. Proceedings of Conferencia APINCO de Ciencia e Tecnologia Avicolas. 4-6, 05: 269- 284.

Hafez, H.M.; Hess, M.; Prusas, C.; Naylor, C.J. and Cavanagh, D. (2000): Presence of avian pneumovirus type A in continental Europe during the 1980s. J. Vet. Med. (B) 47, 629-633.

Hess, M.; Wenzel, R. and Hafez, H.M. (2000): Epidemiological investigation on avian pneumovirus in poultry flocks using nested RT-PCR. Proceedings of the $3^{\text {rd }}$ International Symposium on Turkey Diseases, Berlin. (Ed. Hafez, H. M. ISBN 3-930511-92-4) p. 222-229.

Jirjis, F.F.; Noll, S.L.; Halvorson, D.A.; Nagaraja, K.V.; Martin, F. and Shaw, D.P. (2004): Effects of bacterial coinfection on the pathogensis of Avian Pneumovirus infection in turkeys. Avian Dis., 48, 34-49.

Juhasz, K. and Easton, A.J. (1994): Extensive sequence variation in the attachment $(\mathrm{G})$ protien gene of avian pneumovirus: evidence for two distinct subgroups. J. Gen. Virol. 75, 2873-2880.

Mahmoud, A.H.; Hanan, A. Fahmy; Jehan, A.M. Gafer and Arafa, A. (2008): Investigation on turkey rhinotrachitis in commercial turkeys in Egypt. Proceedings of the $7^{\text {th }}$ International symposium on turkey diseases. Berlin, German Vet. Med. Soc. p. 186- 196.

Naylor, C.J.; Shaw, K.; Britton, P. and Cavanagh, D. (1997): Appearance of type B avian pneumovirus in Great Britain. Avian Pathol. 26, 327-338.

Naylor, C.J.; Britton, P. and Cavanagh D. (1998): The ectodomains but not the transmembrane domains of the fusion proteins of subtypes $\mathrm{A}$ and $\mathrm{B}$ avian pneumovirus are conserved to a similar extent as those of human respiratory syncytial virus. Journal of General Virology: 79, 1393-1398. 
OIE (2008): Turkey rhinotrachitis (avian metapneumovirus). Terrestrial manual. Chapter 2.3.15. Page 590-598.

Randhawa, J.S.; Wilson, S.D.; Tolley, K.P.; Cavanagh, D.; Pringle, C.R. and Easton, A.J. (1996): Nucleotide sequence of the gene encoding the viral polymerase of avian pneumovirus. J. Gen. Virol. 77:3047-3051.

Seal, B.S. (1998): Matrix protein gene nucleotide and predicted amino acid sequence demonstrate that the first US avian pneumovirus isolate is distinct from European strains. Virus Res., 58: 45-52.

Seal, B.S.; Sellers, H.S. and Meinersmann R.J. (2000): Fusion protein predicted amino acid sequence of the first US avian isolate and lack of heterogeneity among other US isolates. Virus Res., 66: 39-147.

Shin, H.J.; Cameron, K.T.; Jacobs, J.A.; Turpin, E.A.; Halvorson, D.A.; Goyal, S.M.; Nagaraja, K.V.; Kumar, M.C.; Lauer, D.C.; Seal, B.S. and Njenga, M.K. (2002): Molecular epidemiology of subgroup $C$ avian pneumoviruses isolated in the United States and comparison with subgroup A and B viruses. J. Clin. Microbiol. 40 (5): 1687-93.

Shin, H.J.; Rajashekara G.; Jirjis, F.F.; Shaw, D.P.; Goyal, S.M.; Halvorson, D.A. and Nagaraja, K.V. (2000): Specific detection of avian pneumovirus (APV) U.S. isolates by RT-PCR. Arch. Virol. 145:1239-1246.

Toquin, D.; Bäyon-Auboyer, M.H.; Eterradossi, N. and Jestin, V. (1999): Isolation of a pneumovirus from a Muscovy duck. Veterinary Record 145, 680. 